слагается из двух составляющих: возможности принять наследство и возможности отказаться от наследства.

1. Фомичева Н. В., Строкова О. Г. Гражданское право. Общая часть. Учебник и практикум для бакалавриата и специалитета. М.: Юрайт, 2019. 408 с.

2. Федчун А.В. Право на оспаривание сделок наследодателя:поиск баланса интересов / А.В. Федчун / Legal concept $=$ Pravovaya paradigma. -2017 . - №4. C.117-125.

3. Гражданский кодекс Российской Федерации (часть третья)" от 26.11.2001 N 146-Ф3 (ред. от 18.03.2019)

4. Юкша Я. А. Гражданское право. В 2 частях. Часть 2. Учебное пособие. М.: РИОР, 2018. 232 с.

5. Гражданское право: Учебник: в 2 т. / С.С. Алексеев, О.Г. Алексеева, К.П. Беляев и др.; под ред. Б.М. Гонгало. М.: Статут, 2016. Т. 1. 511 с.

\title{
Марьин Е.В. \\ Моральные и правовые аспекты монастырского землевладения в освящении князя-икона Вассиана Патрикеева
}

ФГБОУ ВО «Московский государственный университет геодезии и картографии» (МИИГАиК)

(Россия, Москва)

doi: $10.18411 / \mathrm{lj}-05-2021-180$

\section{Аннотация}

В статье анализируется публицистическая деятельность известного русского средневекового публициста, князя-инока Вассиана (Патрикеева). Представлены и проанализированы основные его аргументы, направленные против современной ему практики монастырских хозяйств, распространявших право собственности на большие земельные угодья. Вассиан выстраивает свою аргументацию против вотчинных прав монастырей - религиозно-теоретическую (евангельские заповеди), историческую (примеры древних святых), а также дополняет её аргументацией канонической, ссылками на постановления церковных соборов.

Ключевые слова: Вассиан Патрикеев, монастырское землевладение, церковные земли, нестяжатели, иосифляне, религиозная полемика, древнерусская публицистика.

\section{Abstract}

The article analyzes the journalistic activity of the famous Russian medieval publicist, Prince-monk Vassian (Patrikeev). The article presents and analyzes his main arguments against the contemporary practice of monastic farms, which extended the right of ownership to large land plots. Vassian builds his argument against the patrimonial rights of monasteriesreligious and theoretical (the Gospel commandments), historical (examples of ancient saints), and also complements it with canonical arguments, references to the decisions of church councils.

Keywords: Vassian Patrikeev, monastic land ownership, church lands, nonpossessors, Josephites, religious polemics, Old Russian journalism.

Основное содержание публицистической деятельности Вассиана Патрикеева составляла борьба против вотчинных прав монастырей. «Монастырям сел не подобает держать» [3, с. 224]- эта мысль красной нитью проходит через все творчество князяинока [7]. В этом заключен основной смысл его учения «нестяжательства», которое несет в себе ярко выраженный критический пафос.

Дореволюционная светская историография и либеральная литературная среда концентрировали внимание на декларируемый Вассианом Патрикеевым (но не подтверждаемый даже его личным примером, демагогический в сущности), 
нравственный аспект «нестяжательства», совершенно игнорируя факт его осуждения Православной Церковью за еретические взгляды.

В свою очередь, советская историография выработала особый «почтительный» подход к ересям при изучении еретических движений в истории Православной Церкви на Руси. Еретичество относили, например, к «реформационным движениям» [5, с. 12], видели в нем «проявление гуманизма» $[10$, с. 8] или «характерного феномена западной культуры» $[6$, с. 16] и т.п. Такой же подход характерен для советской историографии и в изучении публицистического творчества Вассиана Патрикеева.

Нам важно отметить, что «нестяжательство», декларируемое Вассианом Патрикеевым, как лишение монастырей их земельной собственности не имеет ничего общего с нестяжанием - как одним из обязательных монашеских обетов.

Говоря, непосредственно о произведениях князя-инока, необходимо отметить, что текстологическое изучение литературного творчества Вассиана Патрикеева, проведенное его самым авторитетным исследователем - Н.А.Казаковой, позволяет сделать вывод о принадлежности ему следующих произведений:

1) «Собрания некоего старца»;

2) «Ответа кирилловских старцев»;

3) «Слова ответна»;

4) «Слова о еретиках»;

5) «Прения с Иосифом Волоцким» [3, с. 219] (А.И. Плигузов оспаривает его принадлежность Вассиану Патрикееву, считая, «что наиболее вероятный его автор - старец Артемий» [ 8, с.277]).

Названными произведениями ограничивается круг тех произведений, которые могут быть включены с достаточной степенью убедительности в число сочинений Вассиана Патрикеева. Несомненно, что литературное наследие Вассиана было гораздо шире: как показывает его последнее полемическое сочинение «Прение с Иосифом Волоцким», Вассиан в своей публицистической деятельности поднимал ряд вопросов, не нашедших отражения в названных произведениях. Очевидно, им были посвящены специальные сочинения князя-инока. Но они на сегодняшний день неизвестны.

Исходным пунктом отрицания вотчинных прав монастырей являлось в сочинениях Вассиана Патрикеева положение о несоответствии вотчинного быта монастырей обетам иноков. Свое первое произведение, направленное против монастырского землевладения - «Собрание некоего старца на воспоминание своего обещания», Вассиан начинает с указания на необходимость для иноков свято хранить свои обеты: «Вдавый себе Богови и вручив ся честному житию, и печатлев свою душу целованием Святого Евангелия пред многими послухи, и прикоснувся десною рукою на поручение честнаго послушания ко своему игумену, должен есть опасно сохранити сия» $[3$, с.224].

Важнейший из обетов иноков - это обет нестяжания, рассматриваемый Вассианом как отказ от вотчинных прав монастырей: «Иноком жити по Евангелию, и по Апостолу, и по Великому Василию - сел не держати, ни владети ими, но жити в тишине и в безмолвии, питаяся своима рукама» [3, с.224]. Так жили древние святые отцы, основатели монастырей, греческих и русских - Пахомий Великий, Савва Освященный, Антоний и Феодосий Печерские и другие, — которые «сел у монастырей не держали... Аще кто и давал им села, и оне не имали, но жили безименно по Евангелию и по своему обещанию» [ 3, с.224].

Из приведенных цитат ясно видно, что у Вассиана провозглашается совершенно определенное отношение к монастырскому землевладению: вотчинный быт монастырей противоречит, с его точки зрения, духу евангельского учения, которому должны были следовать иноки. Помимо ссылок на Евангелие, отрицание вотчинных прав монастырей Вассиан аргументировал историческими примерами - указаниями на нестяжательность древних святых. 
Ту же аргументацию против вотчинного быта монастырей Вассиан развивает и в своем более позднем сочинении - «Слово ответно противу клевещущих истину евангельскую и о иноческом житии и устроении церковном». Основное назначение инока - это следование евангельской заповеди нестяжания: «Господь же рече: Аще хощеши съвершен быти, иди и продай имениа твоа и даждь а нищим, и прииди и последуй Ми. Сиа краткыя глаголы опасне являют иноческое житие, - пишет Вассиан, - в трех сих съборнейших главизнах съобьемлющи и прочаа вся съставляющаа иноческое житие, рекше, нищету, милостыню и всякое братолюбие и състрадание, к симь же и молитву непрестанну с воздержанием и бодростию» [3, с. 257].

Чтобы показать, что вотчинный быт современных ему монастырей является результатом отступления от первоначальной нестяжательности их, Вассиан предлагает обратиться к житиям святых, основателей первых монастырей, - Пахомия, Евфимия, Саввы и других. «Аще и трудолюбно в житиа их приникше, обрящеши их последну нищету возлюбивших, яко многажды и дневнаго хлеба оскудевшим; и обаче сице скудне имевших николи же запустеша свяшон-нй их манастыри, скудости ради нужных, но и паче возряста-ху и. поспешествоваху во всех и умножахуся, своими руками тружающеся и хлеб свой ядуще в поте лица своего, по заповеди», [3, с.265] таковы, с точки зрения Вассиана, результаты обращения к Житиям святых.

Примерно около 1515 года Вассиан приступает к работе над Кормчей. К составлению новой Кормчей Вассиана побудило стремление подкрепить свои публицистические выступления против монастырского землевладения авторитетом правил Номоканона. Составляя свою Кормчую, Вассиан хотел свою прежнюю аргументацию против вотчинных прав монастырей — религиозно-теоретическую (евангельские заповеди), историческую (примеры древних святых) - дополнить аргументацией канонической, ссылками на постановления церковных соборов.

Но во многих Соборных правилах, являвшихся неотъемлемой частью Кормчей, встречались упоминания монастырских сел, противоречащие общему направлению Кормчей Вассиана. Из этого противоречия Вассиан попытался выйти, дав термину «монастырские села» своеобразное толкование. Так, в пояснении к 11-й грани (титуле) Кормчей, сделанном Вассианом, мы читаем: «По сей грани 11, аще именяются села монастырьскиа в правилех, но не иноком повелевает ими владети, но данныа им села от соборныя церкви епископом их хранятся от соборныя церкви икономом, и окорьмляются от него всякыми потребами повелением от епископа их или милостынею христолюбцев, аще не довлеются своим рукоделием» [8, с.72].

Таким образом, монастырские села, упоминаемые в Соборных правилах, Вассиан трактует как села, принадлежащие соборным кафедральным церквам и лишь приданные монастырям с тем, чтобы доходы с них шли на содержание иноков.

Но, указывая, что владение селами и иными имуществами является результатом отступления монастырей от древних уставов, а так же отмечая пагубность влияния монастырского стяжания на нравы иноков, свт. Киприан отнюдь не призывал к ликвидации вотчинных прав монастырей. Напротив, в других посланиях «он ревностно выступал в защиту церковных и монастырских имуществ» [9, с. 137]. Таким образом, осуждение вотчинных прав монастырей у свт. Киприана представляло собой лишь абстрактно-морализирующее рассуждение.

В случае же князя Патрикеева темперамент политического деятеля очень скоро взял в нем верх над монашескими обетами. Вассиан вновь вмешивается в общественнополитическую жизнь в той единственной форме, которая осталась для него возможной,- в форме участия в идеологической и религиозной борьбе.

$$
* * *
$$

1. Буланин Д. М. Переводы и послания Максима Грека: Неизданные тексты. Л., 1984.

2. Дмитриев Л. А. Роль и значение митрополита Киприана в истории древнерусской литературы // ТОДРЛ. Т. ХІХ. Л., 1963. С. 102-103.

3. Казакова Н. А. Вассиан Патрикеев и его сочинения. Л., 1960. 
4. Казакова Н. А. К изучению Кормчей Вассиана Патрикеева // ТОДРЛ. Т. ХХХ. Л., 1974. С. 346.

5. Клибанов А. И. Реформационные движения в России в XIV - первой половине XVI вв. М., 1960.

6. Лурье Я. С. Русские современники Возрождения. Книгописец Ефросин. Дьяк Федор Курицын. Л., 1988.

7. Никольский Е.В. Идея секуляризации церковного землевладения в публицистике князя - инока Вассиана Патрикеева// Аксиологическое пространство русской словесности: традиции и перспективы изучения Материалы международной научной конференции "Кусковские чтения. Аксиологическое пространство русской словесности: традиции и перспективы изучения". 2019. С. 234-244.

8. Плигузов А. И. Кормчая Вассиана Патрикеева // Исследования по источниковедению истории CCCP XIII-XVII вв. М., 1986.

9. Прохоров Г. М., Дробленкова Н. Ф. Киприан // Словарь книжников и книжности Древней Руси. Вып. ІІ. Ч. 1. М., 1988. С. 137.

10. Рыбаков Б. А. Стригольники. Русские гуманисты XIV столетия. М., 1993.

Митин Р.К.

Наследование долгов несовершеннолетними: правовые аспекты

Калужский институт (филиал) ВГУЮ (РПА Минюста России) (Россия, Калуга)

doi: $10.18411 / \mathrm{j}-05-2021-181$

\section{Аннотация}

Актуальность указанной темы обусловлена увеличением числа граждан, имеющих долговые обязательства перед организациями или иными гражданами. При этом растет число несовершеннолетних, назначаемых в качестве наследников по закону или завещанию. Целью данной статьи является выявление проблем, связанных с наследованием имущества детьми, а также управлением долгами их умерших родителей.

Ключевые слова: наследование, наследование долгов, несовершеннолетние наследники, порядок управления имуществом, выплаты по алиментам.

\section{Abstract}

The relevance of this topic is due to an increase in the number of citizens who have debt obligations to organizations or other citizens. At the same time, the number of minors appointed as heirs by law or will is growing. The purpose of this article is to identify problems related to the inheritance of property by children, as well as the management of the debts of their deceased parents.

Key words: inheritance, inheritance of debts, minor heirs, property management procedure, alimony payments.

Развитие института наследования является одним из наиболее важных процессов формирования российского законодательства. Поддержание и обеспечение надлежащего уровня гражданского оборота имущества способствует реализации прав собственности граждан, а также упрочению порядка правопреемства. Однако, как известно, вместе с правами умершего к наследникам переходят и обязанности перед кредиторами. В данном случае возникает ряд вопросов, касающихся распоряжения имуществом и погашения имеющихся долгов.

Наследование несовершеннолетними лицами имущества осуществляется в общем порядке - или по закону или же по завещанию. Ст. 1175 ГК РФ, устанавливающая ответственность наследников по долгам наследодателя, не содержит каких-либо нюансов, касающихся именно прав и интересов несовершеннолетних наследников. [2] 